\title{
Contagious Progression and Distribution of Arsenic in India: A Key Towards Bioremediation
}

\author{
Ankur Bhardwaj*†, Rakesh Kumar Sharma* and Gajendra Bahadur Singh** \\ *Department of Biotechnology \& Life Sciences, Institute of Biomedical Education \& Research, Mangalayatan \\ University, Beswan, Aligarh-202145, Uttar Pradesh, India \\ **University Institute of Biotechnology, Chandigarh University, National Highway 95, Mohali, Chandigarh-140413 \\ Punjab, India \\ $†$ Corresponding author: Ankur Bhardwaj; ankurphd995@gmail.com
}

Nat. Env. \& Poll. Tech. Website: www.neptjournal.com

Received: 20-05-2020

Revised: $18-06-2020$

Accepted: 25-07-2020

Key Words:

Bioremediation

Arsenic

ars operon

Arsenate reductase

Arsenite oxidase

Mining

\begin{abstract}
Arsenic (As) is a renowned threat to the environment and human well-being. Its concentration is increasing year after year in several countries. The utmost pretentious are mining regions of India, as per government surveys and available research findings. Population residing near mining regions are bounded to consume arsenic tainted water in their routine life and evolve various hazardous health problems. Besides many physicochemical techniques at hand for its purification, none are promising. The microbial mediated arsenic detoxification involving oxidation/reduction and extrusion by a membrane-associated efflux pump may perhaps financially acuity and a promising method for bioremediation. The arsenic richness in mining regions triggered the evolution of bacterial cells to come up with a potential mechanism to survive in As rich environment. Microbial extrusion strategy of As in both $\mathrm{As}^{3+}$ and $\mathrm{As}^{5+}$ forms may also be involved in increasing As in abandoned mining regions in underground water. So, to understand the involvement of these bacterial cells in the increment of As in these regions the present study was performed by personally visiting these sites and conversation with local residents. We have witnessed many jaw-dropping truths about As exposure risk to humans and domesticated animals, which has been discussed in this article. This review comprehensively summarizes current studies associated with arsenic exposure, environmental dispersal and its bioremediation through arsenic metabolizing bacteria covering recent developments, pathways, action mechanism and understanding arsenic metabolizers with the depiction of future prospects on arsenic bioremediation from contaminated systems.
\end{abstract}

ventures likewise represents across the board pollution of soil and groundwater (Dontala et al. 2015).

According to the consolidated hazardous chemicals list of the Environmental Protection Agency (EPA) of 2001, the United States, exposure to arsenic causes acute and adverse health issues. In 2001, EPA declared arsenic limits for drinking water $(10 \mu \mathrm{g} / \mathrm{L})$ which is being employed till today. Arsenic pollution extent and its potential danger to human wellbeing have brought about extensive enthusiasm for concentrate microbial species in-charge of the diminishment of arsenic (Mirza et al. 2017). Drinking water mining from shallow tube-wells is among vital pathways for its entrance into human bodies (Chakraborti et al. 2017b). Human contact to arsenic predominantly occurs by utilizing groundwater (cooking or crop irrigation) which have increased inorganic arsenic levels (WHO) in humans as well as plant body. Various geological and other factors were acknowledged enhancing arsenic mobilization, affecting many regions in India (Philp 2015). Arsenic translocation and bio-magnification have also impacted numerous important crops (Chakraborty et al. 2014). 
The As-toxicity relies on its biochemical nature and uses phosphate transporters for entering into a bacterial cell (Nordstrom 2002). Aquaporin mediated As entrance in the cell, blocks the function of many proteins by altering their functional groups. It also affects respiration by binding to PDh (pyruvate dehydrogenase), 2-oxoglutarate dehydrogenase and other enzymes leading to DNA damage by inhibiting its repairing mechanism (Bhattacharjee et al. 2005). Oxidative phosphorylation is caused by As due to hindrance created by it in enzymatic activity (Jomova et al. 2011). Like-wise $\mathrm{As}^{5+}$ structural similarity to phosphate is responsible for its access to active cells, interrupting oxidative phosphorylation (Kumari \& Jagadevan 2016). The ingestion of large doses of arsenic causes fatal health problems (Fig. 1) and prolonged contact produces lesions in skin (Mazumder 2015). Arsenic carcinogenicity is already well known however, its lung cancer mechanism has not well been understood (Wei et al. 2019). Metals serve vital roles (in small quantities) in living beings, serving essential catalytic roles (Ryan et al. 2005). Microorganisms can metabolize metals through various methods (Silver \& Phung 2005). Diverse detoxification strategies were developed by bacteria to encounter arsenic toxicity and among them, one is transforming it to a less lethal form (Turner 2001). Among reduced arsenic species, arsenite is more portable and dangerous while arsenate is less toxic in comparison (Edwards et al. 2000).
National rural drinking water (NRDW) programme has been adapted by State governments for providing clean water to affected habitations (Tomar 2017). An objective of making accessible safe and hygienic drinking water by 2021 , is set by the Government of India (GOI) for 28,000 habitations extremely pretentious with arsenic contamination (Dey 2017). Due to increasing health issues, the Ministry of Drinking Water and Sanitation (MDWS) has launched 'National Water Quality Sub-Mission' for the habitants of affected regions (Chakraborti et al. 2017a). The MDWS has also commissioned around 35 developmental projects for water quality improvement in rural and urban areas (Omar et al. 2017).

According to a recent report demonstrated in Rajya-Sabha (Feb. 2017) from MDWS, various schemes have been executed equipping clean water in pretentious areas of the country. Expanding the reliability of numerous nations on groundwater has increased the focus on safe remediation strategies (Kadushkin et al. 2004). Arsenic expulsion technique in influenced regions could be the only option for a healthy water supply. The arsenic alleviation approach has to be implemented according to specific geographical and socio-economic characteristics of the area.

\section{GLOBAL ARSENIC EPIDEMIOLOGY}

Arsenic is affecting a major World population with several

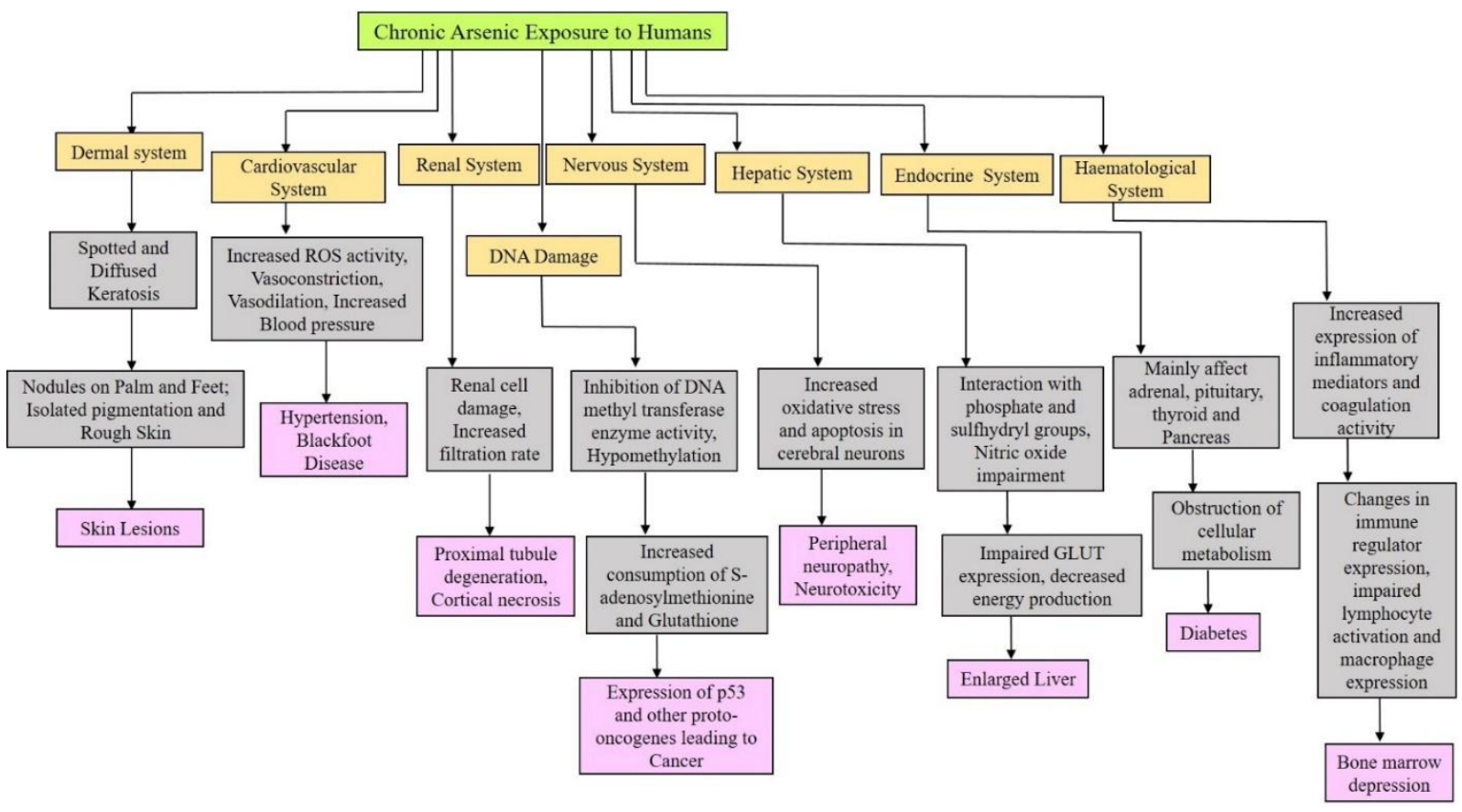

Fig. 1: Arsenic exposure and human health effects. 
impacts and has now become a foremost environmental concern (Chikkanna et al. 2019). Detecting arsenic for a normal person is nearly impossible due to the absence of flavour, colour and aroma. People relying on groundwater having eminent arsenic level are vulnerable to its toxicity risk. Abandoned mines cause arsenic arrival in groundwater leading to an increase in its concentration (Hajalilou et al. 2011). Nowadays research on arsenic accumulation is going on to understand its speciation.

The application of arsenic-rich water for irrigation is a key factor responsible for high soil arsenic accumulation. Soil samples were investigated by Sandhi and co-workers during the ripening stage of rice from different paddy fields and arsenic aggregation was observed to be higher (90 to 210 $\mu \mathrm{g} / \mathrm{kg}$ ) in dehusked grains than in husked grains (Sandhi et al. 2017). Certain ecological advancements contain abnormal arsenic amounts that reach wells and various public water deliveries through leaching (McArthur 2019). Quantitative investigations of groundwater samples of Mongolian regions indicate that arsenic species are vastly associated with $\mathrm{Fe}$ species controlled by geographical and redox factors (Jiang et al. 2015). Arsenite was detected in rice samples from
Korea with concentrations of 28.51 and $51.91 \mu \mathrm{g} / \mathrm{kg}$ (Kwon et al. 2017).

In Chile, the capital of Santiago, millions of tube wells were found containing arsenic $(>50 \mu \mathrm{g} / \mathrm{L})$ and 7600 people are affected (Quinodóz et al. 2019). Various nations specifically, India, Bangladesh and Vietnam are at great risk, where the one-third population is drinking arsenic-polluted water (WHO 2010). Around 57 million individuals are devouring arsenic-contaminated water above recommended limits in India and many other countries (Table 1) (Jha et al. 2017).

\section{EPIDEMIC ARSENIC CONSEQUENCE IN INDIA}

In India, groundwater contamination is severely problematic due to futile purification systems and intermittent floods and monsoon (Kadushkin et al. 2004). Mining, industrialization, ore processing has deleteriously impacted the environment through ecosystem alterations, biodiversity damage and accumulation of toxic pollutants (Singh \& Singh 2016). These activities produce enormous hazardous wastes, left without treatment. Abandoned mines contaminate groundwater by redox events and anaerobic conditions,

Table 1: Worldwide distribution of arsenic (Santra et al. 2013, Herath et al. 2016).

\begin{tabular}{|c|c|c|c|c|}
\hline S.No. & Country & Region & Groundwater Arsenic level $(\mu \mathrm{g} / \mathrm{L})$ & Permissible limit $(\mu \mathrm{g} / \mathrm{L})$ \\
\hline 1 & Afghanistan & Ghazni & $10-500$ & 10 (WHO) \\
\hline 2 & Australia & Victoria (around the gold-mining regions) & $\begin{array}{l}\text { 1-12 (Groundwater); } \\
1-73 \text { (Drinking-water); } \\
1-220 \text { (Surface water) }\end{array}$ & NIL \\
\hline 3 & Bangladesh & Noakhali & $<1-4730$ & $50(\mathrm{WHO})$ \\
\hline 4 & Brazil & $\begin{array}{l}\text { Minas Gerais } \\
\text { (Southeastern Brazil) }\end{array}$ & $\begin{array}{l}0.4-350 \\
\text { (Surface water) }\end{array}$ & 10 (WHO) \\
\hline 5 & Cambodia & $\begin{array}{l}\text { Prey Veng and } \\
\text { Kandal-Mekong delta }\end{array}$ & $\begin{array}{l}\text { Up to } 900 \\
1-1610\end{array}$ & $10(\mathrm{WHO})$ \\
\hline 6 & Canada & $\begin{array}{l}\text { Nova Scotia } \\
\text { (Halifax County) }\end{array}$ & $1.5-738.8$ & 10 (WHO) \\
\hline 7 & China & - & $50-4440$ & $50(\mathrm{WHO})$ \\
\hline 8 & Finland & Southwest Finland & $17-980$ & 10 (WHO) \\
\hline 9 & Greece & Fairbanks (mine tailings) & Up to 10,000 & $10(\mathrm{WHO})$ \\
\hline 10 & India & West Bengal Uttar Pradesh & $10-3200$ & $50(\mathrm{WHO})$ \\
\hline 11 & Japan & Fukuoka Prefecture (southern region) & $1-293$ & 10 (WHO) \\
\hline 12 & Mexico & Lagunera & $8-620$ & 25 \\
\hline 13 & Nepal & Rupandehi & Up to 2620 & 50 \\
\hline 14 & Pakistan & Muzaffargarh (southwestern Punjab) & Up to 906 & 50 \\
\hline 15 & Taiwan & - & $10-1820$ & 10 (WHO) \\
\hline 16 & Thailand & Ron Phibun & $1->5000$ & 10 (WHO) \\
\hline 17 & USA & Tulare Lake Red River Delta & Up to 2600 & 10 (USEPA) \\
\hline 18 & Vietnam & $\begin{array}{l}\text { (Northern Vietnam) } \\
\text { Mekong Delta (Southern Vietnam) }\end{array}$ & $<1-3050$ & 10 (WHO) \\
\hline
\end{tabular}


accumulating particulates in groundwater sources, hence, contaminated water treatment is considerably essential before consumption (Ayangbenro \& Babalola 2017). It has been reported that even after abandoning the mining activity, the concentration of As increases, which may be due to the microbial transforming system (Zhang et al. 2019). It adversely affects the flora and fauna of mining regions.

With the aim of providing safe drinking water, a number of wells were developed earlier (advocated by UNICEF and World Bank) resulted in decreased newborn mortality and diarrheal disease by $50 \%$. But as per investigation, approximately one among five wells are now arsenic tainted above EPA standard (Chakraborti et al. 2008). Nine hundred villages were found to have arsenic above the standard limit, where groundwater is mostly extracted by deep tube-wells having higher 'As' sediments (Shah 2010).

WHO has reported many regions of West-Bengal and other states, consuming high arsenic-contaminated drinking water (Ahamed et al. 2006). Government programs to provide 'safe' drinking-water, controlled arsenicosis, but in a few areas problem is still the same. The districts situated nearby Ganga and Gandaki river were scrutinized and found that the arsenic affected far above WHO defined limit (10 $\mu \mathrm{g} / \mathrm{L})$ (Shah 2010). In 2016, the Mahavir Cancer Institute, Bihar analysed 23,000 new malignancy patients, and these cases were due to arsenic poisonous quality (Chakraborti et al. 2017b). A number of other states like, Jharkhand, Madhya Pradesh, Chhattisgarh and Assam are facing arsenic tainted water issues. Sahibganj district of Jharkhand situated in the middle Ganges plain has arsenic $>50 \mu \mathrm{g} / \mathrm{L}$ (Ramanathan et al. 2006). People residing in those areas have no alternative and are continuing with the same exposed risk (Chakraborti et al. 2003). Arsenic disasters are happening today and most outstandingly due to drinking water contamination. More than 40 million individuals in India, are exposed to 50 $\mu \mathrm{g} / \mathrm{L}$ or above arsenic. The scenario is equally bad in some districts of Bihar, West Bengal and Uttar Pradesh (Milton et al. 2001). Chhattisgarh state was parted from Madhya Pradesh (year 2000). Border regions of MP and Chattisgarh district are mostly affected by arsenic contamination. In 1999 Rajnandangaon district of Madhya Pradesh was reported to have high groundwater arsenic concentration and above a million of the population of Rajnandangaon is consuming arsenic polluted water (Patel et al. 2017). Some dug-wells, along with hand tube-wells, are contaminated with higher $(520 \mu \mathrm{g} / \mathrm{L})$ arsenic concentration in West Bengal and Rajnandgaon (Saha \& Ray 2019).

The $\mathrm{As}^{3+}$ concentration in groundwater of Barasat (Gangetic plain), West Bengal was found excessive than $\mathrm{As}^{5+}$ (10 to $538 \mu \mathrm{g} / \mathrm{L}$ ), showing reducing conditions (Kar et al. 2010).
The reduction activity of iron/sulphur oxides was a foremost mechanism for arsenic release into groundwater (Sichone 2019). Several states were also discovered as influenced with maximum arsenic level (3,700 $\mu \mathrm{g} / \mathrm{L})$ (Tchounwou et al. 2019).

Groundwater arsenic release mechanism was investigated in Balia district, U.P and $468 \mu \mathrm{g} / \mathrm{L}$ concentration was found at depths of 30-33 m (Chauhan et al. 2009). Groundwater arsenic concentration of Sahibganj district, Jharkhand was highest in post-monsoon $(133 \mu \mathrm{g} / \mathrm{L})$ compared to monsoon $(98 \mu \mathrm{g} / \mathrm{L})$ and pre-monsoon (115 $\mu \mathrm{g} / \mathrm{L})$ (Alam et al. 2016). The water standard of the Dhanbad area, Jharkhand was not up to the mark (Masto et al. 2011). Hydro-geochemical processes and isotropic rock tracing of aquifers were studied in the East-Singhbhum area of Jharkhand. Temporal and seasonal differences affect groundwater quality significantly (shallow aquifers) due to disparity in flow, recharge, geochemical processes. Groundwater arsenic concentration of Bishnupur locality, Manipur was found highest in post-monsoon and increase is anticipated in nearby future (Chakraborti et al. 2018).

Many people of West-Bengal are affected by arsenic exposure, as per the latest report presented in Lok-Sabha. Although State governments are determined to manage the arsenic peril, still more is left to finish (Gupta \& Singh 2019). Since the skill for arsenic elimination from water is novel and expensive, there is a progress lag in setting water management plants (Shan et al. 2019). Comprehensive detail on groundwater, Kolkata Municipal Corporation (KMC) stated a higher arsenic level (>50 $\mu \mathrm{g} / \mathrm{L})$ (Chakraborti et al. 2017a). A proceeding of Lok Sabha, 2017 by MDWS, says that states like Himachal Pradesh, Punjab, Haryana, Assam, Arunachal Pradesh, Karnataka, Kerala and many additional regions are moderately or severely affected with arsenic (soil or water) contamination (Ali et al. 2019).

\section{ARSENIC DETOXIFICATION GENES}

The majority of microorganisms have evolved with arsenic detoxification systems (Yan et al. 2019). Various studies elucidating its molecular processes were conducted against many microorganisms. Microbes deliberate arsenic detoxification with the assistance of the ars operon framework (Thul et al. 2019). This operon possesses either three ( $\operatorname{arsR}, \mathrm{B}, \mathrm{C})$ or five (arsR, A, B, C, D) gene components (Table 2). This (ars) operon exists either on plasmids or integrated with genome (Firrincieli et al. 2019). The operon (ars) gene encrypts proteins for repression in absence of arsenic, arsenate reduction, its efflux supporting detoxification system. The ars homologs were studied in diverse biological structures like; fungi, plant and animals (Fernández et al. 2014). 


\section{MICROBIAL ARSENITE RESISTANCE}

Microbes evolved mechanism for enzymatic oxidation $\left(\mathrm{As}^{3+}\right.$ to $\mathrm{As}^{5+}$ ) for arsenite or reduction $\left(\mathrm{As}^{5+}\right.$ to $\mathrm{As}^{3+}$ ) for arsenate. They do carry redox events and are imperative players in the arsenic geocycle (Turner 2001). Bacteria resist their toxic effects by preventing their intake or actively exporting the arsenicals or by modifying them enzymatically or chemically. Therefore paramount search for more oxidizing (arsenite) bacteria concerning bioremediation is greatly significant (Verma \& Kuila 2019). Many microorganisms show resistance to arsenic especially arsenate, while there are only a few bacterial isolates known exhibiting arsenite resistance (Tian et al. 2019). Arsenite concentration was proved lethal on or above $200 \mu \mathrm{g} / \mathrm{L}$ for many bacteria. However, arsenite directly can be methylated by $P$. alcaligenes (arsenite S- adenosylmethionine methyltransferase) (Zhang et al. 2015). Arsenite oxidation attenuates toxicity, provided its re-conversion in the cell does not happen. Bacteria harbour transport protein for both arsenic valencies and their transformation catalysing enzymes (Oremland \& Stolz 2003). Presently, it is typically assumed that arsenite oxidizing microbes can harbour both oxidase and reductase enzymes. Both enzyme system in arsenic resistant isolate was found, however, the simultaneous occurrence of two enzymatic systems jeopardize the bioremediation process (Dunivin et al. 2019).

\section{SOLUBILIZATION, MOBILIZATION AND UPTAKE OF ARSENIC}

Arsenic solubilization depends on its speciation and transformation (Smedley \& Kinniburgh 2002, Cullen \& Reimer 1989). Arsenic is additionally found in different methylated forms in the mine drainage system and geothermal inputs. Anaerobic condition in the underground region holds the highest arsenic concentration, where it favours the geochemical conditions for its solubilization (Cullen \& Reimer 1989). Fe-Mn oxides at the water-sediment interface scavenge arsenic from mine tailings and from contaminated water that causes As concentrations to remain enriched in the upper sediments even after mine tailings have been ceased (Sprague \& Vermaire 2018).

Structural similarity of $\mathrm{As}^{3+}$ and $\mathrm{As}^{5+}$ to phosphate

Table 2: Characterized arsenic resistance gene cluster among microorganisms.

\begin{tabular}{|c|c|c|c|}
\hline S.No & Name of organism & ars genes & References \\
\hline 1 & E. coli plasmid R773. & $\operatorname{arsR}, \mathrm{A}, \mathrm{B}, \mathrm{D}, \mathrm{C}$ & Hedges \& Baumberg 1973 \\
\hline 2 & Staphylococcus xylosus plasmid pSX267. & $\operatorname{arsR}, \mathrm{B}, \mathrm{C}$ & Rosenstein et al. 1992 \\
\hline 3 & Staphylococcus aureus plasmid pI258 & $\operatorname{arsR}, \mathrm{B}, \mathrm{C}$ & Ji \& Silver 1992 \\
\hline 4 & E coli W3110 & $\operatorname{arsR}, \mathrm{B}, \mathrm{C}$ & Carlin et al. 1995 \\
\hline 5 & Yersiniae sp. & $\operatorname{arsR}, \mathrm{B}, \mathrm{C}, \mathrm{H}$ & Neyt et al. 1997 \\
\hline 6 & $\begin{array}{l}\text { Acidiphilium multivorum AIU } \\
301 \text { plasmid pKW301 }\end{array}$ & $\operatorname{arsR}, \mathrm{D}, \mathrm{A}, \mathrm{B}, \mathrm{C}$ & Carlin et al. 1995 \\
\hline 7 & Bacillus subtilis & $\operatorname{arsR}, \mathrm{B}, \mathrm{C}$ ORF2 & Sato \& Kobayashi 1998 \\
\hline 8 & Pseudomonas aeruginosa & $\operatorname{arsR}, \mathrm{B}, \mathrm{C}$ & Cai et al. 1998 \\
\hline 9 & Acidithiobacillus ferrooxidans & $\operatorname{arsR}, C$ and $\operatorname{ars} B, H$. & Butcher et al. 2000 \\
\hline 10 & Pseudomonas fluorescens strain MSP3 & $\operatorname{arsR}, \mathrm{B}, \mathrm{C}$ & Prithivirajsingh et al. 2001 \\
\hline 11 & Synechocystis sp. Strain PCC 6803 & $\operatorname{arsB}, \mathrm{H}, \mathrm{C}$ & López-Maury et al. 2003 \\
\hline 16 & Shewanella species ANA-3 & $\operatorname{arsR}, \mathrm{B}, \mathrm{C}$ & Saltikov et al. 2003 \\
\hline 12 & Halobacterium sp. Strain NRC-1 & $\operatorname{arsA}, \mathrm{D}, \mathrm{R}, \mathrm{C}, \operatorname{arsR} 2, \mathrm{M}$ & Wang et al. 2004 \\
\hline 13 & Corynebacterium glutamicum ATCC 13032 & $\operatorname{arsR}, \mathrm{B}, \mathrm{C}$ & Ordóñez et al. 2005 \\
\hline 14 & Sinorhizobium meliloti. & arsR,apqs $\mathrm{C}$ & Yang et al. 2005 \\
\hline 15 & Acidithiobacillus caldus & $\operatorname{arsD}, \mathrm{A}, \mathrm{B}$ & Kotze et al. 2006 \\
\hline 17 & Streptomyces sp. Strain FR-008. & $\operatorname{arsR}, \mathrm{O}, \mathrm{B}, \mathrm{T}, \mathrm{C}$ & Wang et al. 2006 \\
\hline 18 & Leptospirillum ferriphilum & $\operatorname{arsR}, \mathrm{B}, \mathrm{C}, \operatorname{arsR}, \mathrm{C}, \mathrm{D}, \mathrm{A}, \mathrm{B}$ & Fournier et al. 2006 \\
\hline 19 & Acinetobacter baumannii & $\operatorname{arsR}, \mathrm{B}, \mathrm{H}, \mathrm{C}$ & Fournier et al. 2006 \\
\hline 20 & Ochrobactrum tritici SCII24T & $\begin{array}{l}\operatorname{arsR}, A, B, D \text { and } \\
\operatorname{arsR}, C, H, A C R 3\end{array}$ & Branco et al. 2008 \\
\hline
\end{tabular}

Note: (i) arsR (arsenical resistance operon repressor), arsB (arsenical pump membrane protein), arsC (arsenate reductase), arsH (unknown), arsD (arsenic operon regulator), arsA (ATPase subunit). (ii) arsR, B, C makes the main detoxification system, arsD and arsA are supporting proteins. 
typically aid prokaryotic cells for their uptake through various transporters (Fig. 2). More specifically, the Pitphosphate transporter is in-charge of arsenate uptake in E.coli cells (Willsky \& Malamy 1980). Pst-phosphate transporter is also found transporting arsenate in some bacterial cells but at a low level than "Pit" (Bertin et al. 2011). Microbial flora which is continually presented to high measures of arsenate express just "Pst" according to lessen arsenate take-up (Meng et al. 2004). In E.coli, GIpF (aquaglyceroporins) is stated for foremost $\mathrm{As}^{3+}$ uptake (Banerjee et al. 2018). Dissimilatory Arsenate Reducing Bacteria (DARB) phylogenetically belong to a diverse group and respire $\mathrm{As}^{5+}$ by reducing it anaerobically. DARB own a conserved arsenate reductase (arrA) gene, essential for reduction system (Burton et al. 2014). It is mostly utilized biomarker estimating variations in arsenic reducing microbes across different environments. Most bacteria utilize a similar process of As detoxification involving its uptake, reduction and extrusion using an efflux pump (Kumari \& Jagadevan 2016).

\section{ARSENITE OXIDATION $\left(\mathrm{AS}^{3+} \mathrm{TO} \mathrm{AS}^{5+}\right)$}

Oxidation of $\mathrm{As}^{3+}$ represents a promising detoxification process that allows microorganisms to tolerate their toxic levels in tainted locations (Santini \& Hoven 2004). So far, isolated arsenite oxidising prokaryotes can be grouped in two categories: (i) Chemolithoautotrophs (aerobes or anaerobes, using arsenite as electron donor and $\mathrm{CO}_{2} / \mathrm{HCO}_{3}{ }^{-}$as specific carbon source) (ii) Heterotrophs (grow in organic matter) (Oremland et al. 2002). Chemolithoautotrophic bacteria NT-26 and MLHE-1 oxidizes $\mathrm{As}^{3+}$ to $\mathrm{As}^{5+}$ using oxygen and $\mathrm{NO}_{3}{ }^{-}$as electron acceptor (Ellis et al. 2001). Several heterotrophic bacteria are persuaded to oxidise $\mathrm{As}^{3+}$ provided in growing media using arsenite oxidase. Arsenite oxidase activity was measured biochemically in presence of azurin or cytochrome-C (Pandey et al. 2009). Yet, at the alike period, it looks that most ecological isolates don't have this potential, in spite of the fact that many microorganisms were recognized having arsenite oxidase gene, which proves that arsenite oxidase is the most important factor for counteracting arsenic toxicity. Microorganisms can indirectly disturb arsenic mobility via sulphate reduction, iron-oxide reduction and mineral dissolution by oxidation (McArthur et al. 2004). The $\mathrm{As}^{3+}$ oxidation to $\mathrm{As}^{5+}$ (a less toxic form of arsenic) occurs due to bacterial arsenite oxidase in the peri-plasm of microorganism (Rosen 2002). A sensor kinase (AoxS) recognizes the presence of $\mathrm{As}^{3+}$ and activates a controller protein (AoxR). AoxR is a point control for aox operon clubbed with RpoN (an option of 454 of RNA polymerase) (Satyapal et al. 2016). The RpoN is the requisite factor for

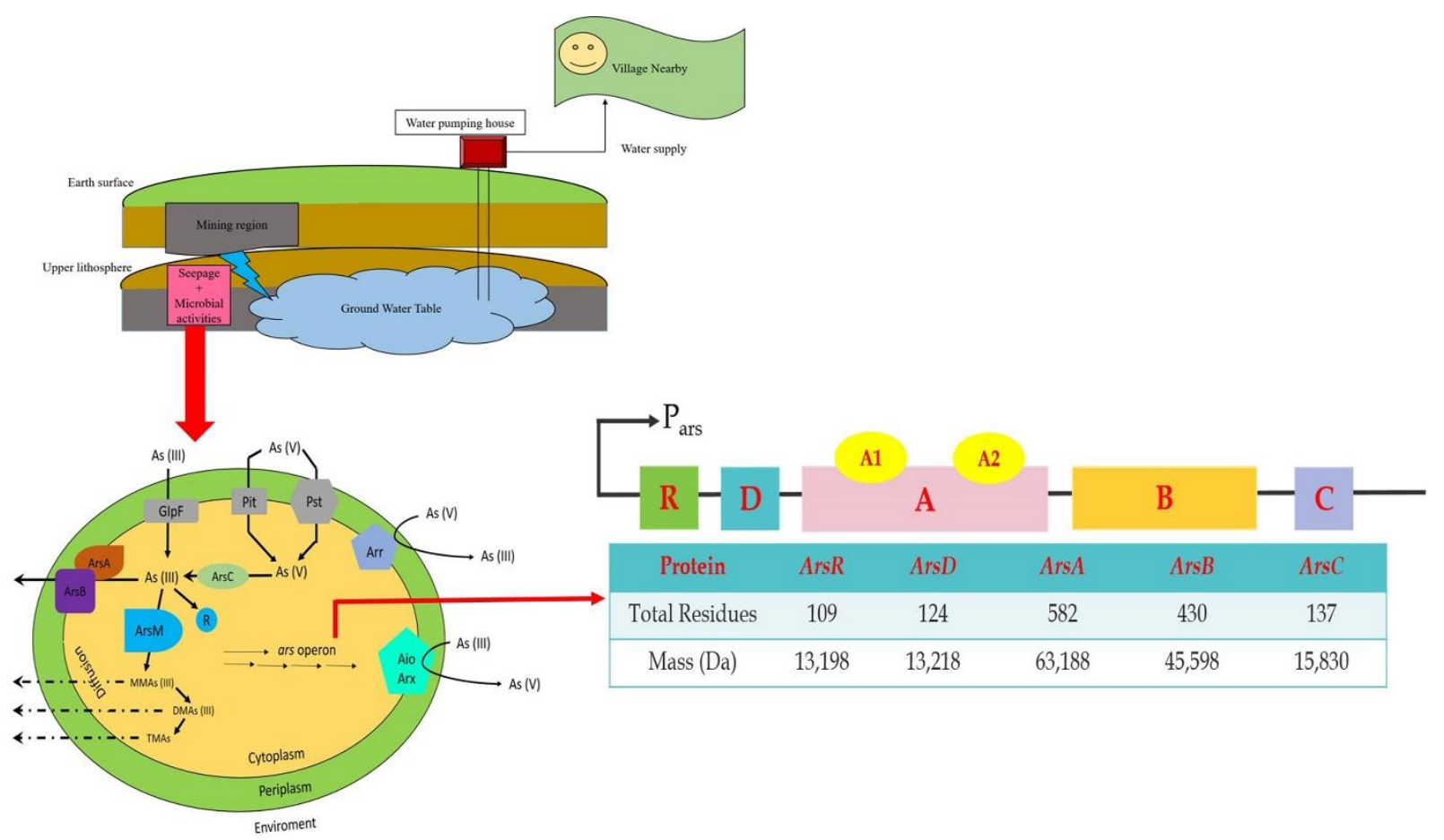

Fig. 2: Pandect of arsenic seepage in groundwater and bacterial interaction. The development of wells and human activities quickens this process by providing necessary oxidants. 
the transcriptional onset of aox operon, the products of which are transferred to peri-plasm by 'Tat' protein in A. tumefaciens. In peri-plasm, 'Tat' is engaged in the oxidation of $\mathrm{As}^{3+}$ (Shankar \& Shanker 2014).

\section{ARSENATE REDUCTION $\left(\mathrm{AS}^{5+} \mathrm{TO} \mathrm{AS}^{3+}\right)$}

Arsenate uptake by the bacterial cell is done by dual phosphate transporters Pst (specifically) and Pit (generally). Arsenite expulsion is finished by (i) carrier-mediated arsenite protein and (ii) through ATPase engaged in arsenite translocation (Shankar \& Shanker 2014). Bacteria harbour two systems for arsenate reduction; cytoplasmic and periplasmic reduction systems. When $\mathrm{As}^{5+}$ is intruded by Pst/Pit transporters (membrane), the arsC (arsenate reductase) reduces it to $\mathrm{As}^{3+}$ followed by extrusion using ars AB pump (Biswas et al. 2019). In cytoplasmic reduction arsC uses glutaredoxins providing reducing potential. In the reaction cascade (Fig. 3), arsenate first unites with an anionic site of arsC forming an arsenate thioester transition with the active site and reduced by glutathione, extruding arsenite (Hare et al. 2019).

Various arsenic forms display different toxicity degrees. Among organic acids of arsenic MMAV (monomethylarsonic acid) and DMAV (dimethylarsinic acid) are barely harmful than inorganic arsenic, whereas MMAIII (monomethylarsonous acid) and DMAIII (dimethylarsonous acid) are highly toxic (Santra et al. 2013). Different arsenic metabolizing bacteria are classified into arsenite oxidizing and reducing (arsenate) bacteria which are skilled in coinciding in the environment, demonstrating a fact that they do play an essential part in metabolizing arsenic (Yan et al. 2019).

\section{ARSENIC BIOREMEDIATION}

Bioremediation technology for eliminating hazardous metals have gained considerable importance over the years.
Microbial biosorbents are eco-friendly, cost-effective and a competent substitute for remediating arsenic (Sylvia et al. 2005). The flexibility of microorganisms to detoxify huge pollutants range makes bioremediation an innovative strategy in this regard (Singh 2014). Bioremediation skill relies on encouraging the growth of specific micro-flora that are indigenous to the specified contaminated sites and are capable to perform desired activities (Dixit et al. 2015).

The arsenic inescapability in nature has constrained the development of resistant mechanism in specific microorganisms utilising As in metabolism. K. pneumonia, a gram-negative, non-motile, rod-shaped bacteria possess the ability to oxidize $\mathrm{As}^{3+}$ and reduce $\mathrm{As}^{5+}$ (Daware \& Gade 2015). It is also reported to have high resilience regarding both arsenate/ arsenite. Through the transformation assay redox ability of $K$. pneumonia towards arsenic was determined to clarify the detoxification mechanism (Batool \& Rehman 2017). Although arsenic bioremediation has received great consideration, still this technology hasn't been implemented at commercial or field-scale to rectify contaminated sites. For successful bioremediation, the design requires three main factors which are: bacteria should exist in arsenic-contaminated sites, should bear high metabolic capacities and could perform under distinct environmental conditions (Nookongbut et al. 2017). Recent investigation depicted, purple non-sulphur Rhodopseudomonas bacteria (R. palustris \& R. faecalis) are attractive organisms for application in arsenic bioremediation as they possess the most versatile growth modes and can flourish under a variety of conditions (Zhao et al. 2015). Bacterial nucleotide sequence having ars operon encodes for various regulatory components like arsA, arsB, arsC, arsD and arsR respectively (Table 3 ).

Recent advances in various biotechnological tools have prompted the beginning of a few non-conventional bioremediation strategies advancing their components and
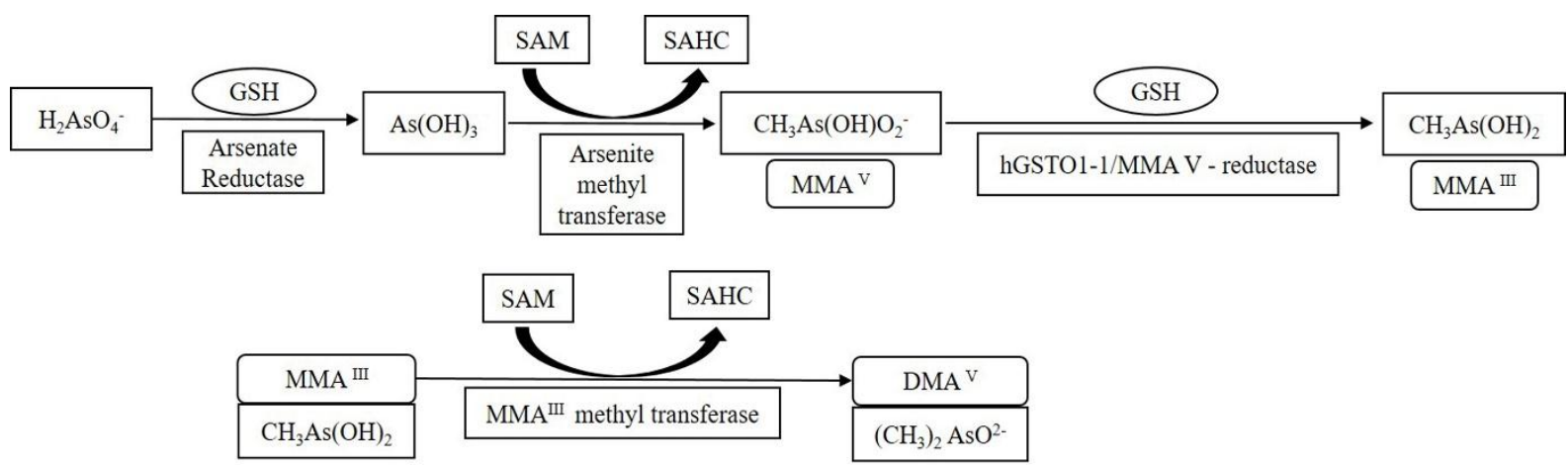

Note: GSH (Glutathione), SAM (S-adenosyl-L-methionine), SAHC (S-adenosyl-L-homocysteine), hGSTO1-1 (human glutathione-S-transferase omega 1-1), MMAIII (monomethylarsonous acid), DMAIII (dimethylarsinous acid).

Fig. 3: Enzymatic method for arsenate reduction. 
Table 3: The ars operon genes and their putative function (Branco et al. 2008).

\begin{tabular}{|ll|}
\hline ORF & Putative function \\
\hline arsR & Regulatory Protein \\
$\operatorname{arsD}$ & Regulatory Protein/Chaperone protein \\
$\operatorname{ars} A$ & Oxyanion-translocating ATPase \\
$\operatorname{arsB}$ & Arsenite membrane pump \\
$\operatorname{arsC}$ & Arsenate reductase \\
\hline
\end{tabular}

performance under diversified natural conditions (Gorny et al. 2018, Palit et al. 2019). Metallothioneins (MTs) are low molecular weight proteins, introduced recently and found in a variety of microorganisms. The cysteine-rich amino acid content of MTs have a greater binding affinity with heavy metals and are efficiently suitable for remediating them at low concentrations (Ma et al. 2011). Recombinant E.coli plasmid with a copy of the MT gene was constructed resulting in a three times increase in bioaccumulation of arsenic (Ma et al. 2011). Voluntary $\mathrm{As}^{3+}$ oxidation at the anode of microbial fuel cells (MFCs) with bioelectricity production was also studied and evaluated ( $\mathrm{Li}$ et al. 2016).

\section{CONCLUSION AND DISCUSSION}

The bacterial arsenic encounter varies greatly among bacterial species. Various bacterial cells were recognized harbouring genes for metabolizing and transforming arsenic species. The Arsenic oxidizing ability of bacterial isolates are well understood and many microbes were being diagnosed and isolated. Arsenic reducing ( $\mathrm{As}^{5+}$ to $\mathrm{As}^{3+}$ transformation) property of bacterial cells are not very well understood, so emphasis should be given in this area as it is too dangerous for the biotic community as well as humans. It has already been reported that in the abandoned mining regions the concentration of arsenite is increasing year after year minutely. This is because the native bacterial cells take up arsenate, reduce and extrude arsenite in the underground environment. This process increases the arsenite concentration in underground water severely, making it unfit for drinking and irrigation purpose. The arsenite when consumed by humans for a long period, leads to various abnormal deformities, as reported in this review. Crops if grown on As contaminated soil or irrigated with As contaminated water, either sequester it or accumulate it. This process further leads to the development of crops that are not suitable for human or animal consumption.

When we visited some contaminated regions of MP and Jharkhand, we came to know about a fact by talking to the native people, that none individual is survived above 52 years of age. The living population, especially adults have developed skin lesions (grey or black spots) on their palms, foot and front abdominal region. We also came to know that, if they use those crop plants which are being grown of contaminated soil, as fodder for milk yielding animals like cow and buffalo, they gradually become weak and decreases the milk yielding capacity and finally, dies within 10 to 12 months. Likewise, many regions are there in India, facing these types of moderate to severe problems. Government and non-government agencies are also playing their part to improve the vegetation and livelihood of arsenic affected regions, but it is not up to the mark. Every year the problem persists and increases in a dramatic mode. So, biological remediation methods employing bacterial community may prove a valuable and cost-effective method, to achieve arsenic decontamination from affected regions.

Bacterial activity and various factors (biotic or abiotic) including complexation, sorption, precipitation, detoxification, redox events impacts the fate of arsenic. More profound knowledge regarding $\mathrm{As}^{3+}$ oxidizers dispersal and metabolic pathways in the natural environment could be a plausible marker for arsenic remediation. However, there are many gaps in the area that needs attention and resolved before exploring in-situ bioremediation as a viable treatment option. Notwithstanding the antiquated origin and wide dispersion of arsenite oxidase in an anoxic environment, a comprehension on its part and effect on regular habitat is yet inadequate. The current improvements in metabolic pathways engaged in arsenic metabolization are yet incomplete and need exhaustive study. This review provides a deeper understanding of the distribution of its metabolizers in the natural environment and depicts future prospects for remediating arsenic. The use of an integrated approach of biomarkers of arsenic exposure and early genotoxic effects will provide a better understanding and mechanistic insight into the health risks of arsenic exposure. The information obtained here highlights the importance of the prevention of arsenic exposure and the need for effective strategies to reduce the risk for the development of diseases associated with such exposure.

\section{FUTURE PROSPECTS}

The profligate growing industry and advancement in technology have put heavy metals encumbrance on the environment contaminating water and soil. As the conventional approaches are slow, complex and expensive, microbial remediation strategies help to surmount such situation. Existing technologies still need modification on a pilot-scale and to be implemented effectively to remove these contaminants in a cost-effective and user-friendly mode. So, it is unambiguously suggested that sheltered and 
effective advances ought to indorse for arsenic expulsion from drinking water. Microbial assisted bioremediation strategy has some margins but still grants a secured and swift way for remedying contaminated sites. Microorganisms play a crucial role in remediating arsenic from the underground environment through the genes harboured by them. If the mechanisms and functions of these genes can be understood, they can be easily employed in the construction of genetically modified organisms (GMOs). The GMOs could be the best significant turning point that can concurrently endeavour on several heavy metals. Essentially, a more profound investigation is required to boast proficiency of GMOs. Manipulation in the exterior membrane can be discouraging for its uptake and even on expressing precise transforming gene, further boost the bioremediation capability by employing GMOs.

\section{REFERENCES}

Ahamed, S., Sengupta, M.K., Mukherjee, A., Hossain, M.A., Das, B., Nayak, B., Pal, A., Mukherjee, S.C., Pati, S. and Dutta, R.N. 2006. Arsenic groundwater contamination and its health effects in the state of Uttar Pradesh (UP) in upper and middle Ganga plain, India: a severe danger. Sci. Tot. Environ., 370: 310-322.

Alam, M.O., Shaikh, W.A., Chakraborty, S., Avishek, K. and Bhattacharya, T. 2016. Groundwater arsenic contamination and potential health risk assessment of Gangetic Plains of Jharkhand, India. Exposure and Health, 8: 125-142.

Ali, S., Fakhri, Y., Golbini, M., Thakur, S.K., Alinejad, A., Parseh, I., Shekhar, S. and Bhattacharya, P. 2019. Concentration of fluoride in groundwater of India: A systematic review, meta-analysis and risk assessment. Groundwater Sustain. Develop. J., 9: 100199-100224.

Ayangbenro, A.S. and Babalola, O.O. 2017. A new strategy for heavy metal polluted environments: a review of microbial biosorbents. Int. J. Environ. Res. Public Health, 14: 94-105.

Banerjee, A., Jhariya, M., Yadav, D. and Raj, A. 2018. Micro-remediation of metals: a new frontier in bioremediation. In: Hussain C. (eds.) Handbook of Environmental Materials Management. Springer, Cham, 1-36.

Batool, K. and Rehman, Y. 2017. Arsenic-redox transformation and plant growth promotion by purple nonsulfur bacteria Rhodopseudomonas palustris CS2 and Rhodopseudomonas faecalis SS5. BioMed Res. Int., 11: 1-8.

Bertin, P.N., Heinrich-Salmeron, A., Pelletier, E., Goulhen-Chollet, F., Arsène-Ploetze, F., Gallien, S., Lauga, B., Casiot, C., Calteau, A. and Vallenet, D. 2011. Metabolic diversity among main microorganisms inside an arsenic-rich ecosystem revealed by meta-and proteogenomics. ISME, J., 5: 1735-1747.

Bhattacharjee, S., Chakravarty, S., Maity, S., Dureja, V. and Gupta, K. 2005. Metal contents in the groundwater of Sahebgunj district, Jharkhand, India, with special reference to arsenic. Chemosphere, 58: 1203-1217.

Bhattacharya, P., Welch, A.H., Stollenwerk, K.G., Mclaughlin, M.J., Bundschuh, J. and Panaullah, G. 2007. Arsenic in the environment: biology and chemistry. Sci. Tot. Environ., 379: 109-120.

Biswas, R., Vivekanand, V., Saha, A., Ghosh, A. and Sarkar, A. 2019. Arsenite oxidation by a facultative chemolithotrophic Delftia spp. BAs29 for its potential application in groundwater arsenic bioremediation. Int. Biodeterior. Biodegrad., 136: 55-62.

Branco, R., Chung, A.P. and Morais, P.V. 2008. Sequencing and expression of two arsenic resistance operons with different functions in the highly arsenic-resistant strain Ochrobactrum tritici SCII24T. BMC, Microbiol., 8: 95-105.

Burton, E.D., Johnston, S.G. and Kocar, B.D. 2014. Arsenic mobility during flooding of contaminated soil: the effect of microbial sulfate reduction. Environ. Sci.Technol., 48: 13660-13667.

Butcher, B.G., Deane, S.M. and Rawlings, D.E. 2000. The chromosomal arsenic resistance genes of Thiobacillus ferrooxidans have an unusual arrangement and confer increased arsenic and antimony resistance to Escherichia coli. Appl. Environ. Microbiol., 66: 1826-1833.

Cai, J., Salmon, K. and Dubow, M.S. 1998. A chromosomal ars operon homologue of Pseudomonas aeruginosa confers increased resistance to arsenic and antimony in Escherichia coli. Microbiol., 144: 2705-2729.

Carlin, A., Shi, W., Dey, S. and Rosen, B.P. 1995. The ars operon of Escherichia coli confers arsenical and antimonial resistance. J. Bacteriol., 177: 981-986.

Chakraborti, D, Biswas, B., Chowdhury, T.R., Basu, G., Mandal, B., Chowdhury, U., Mukherjee, S., Gupta, J., Chowdhury, S. and Rathore, K. 1999. Arsenic groundwater contamination and sufferings of people in Rajnandgaon district, Madhya Pradesh, India. Curr. Sci., 77: 502-504.

Chakraborti, D., Das, B., Rahman, M.M., Nayak, B., Pal, A., Sengupta, M.K., Ahamed, S., Hossain, M.A., Chowdhury, U.K. and Biswas, B.K. 2017a. Arsenic in groundwater of the Kolkata Municipal Corporation (KMC), India: Critical review and modes of mitigation. Chemosphere, 180: 437-447.

Chakraborti, D., Rahman, M.M., Das, B., Chatterjee, A., Das, D., Nayak, B., Pal, A., Chowdhury, U.K., Ahmed, S. and Biswas, B.K. 2017 b. Groundwater arsenic contamination and its health effects in India. Hydrogeol. J., 4: 1165-1181.

Chakraborti, D., Singh, E.J., Das, B., Shah, B.A., Hossain, M.A., Nayak, B., Ahamed, S. and Singh, N.R. 2008. Groundwater arsenic contamination in Manipur, one of the seven North-Eastern Hill states of India: a future danger. Environ. Geol., 56: 381-390.

Chakraborti, D., Singh, S.K., Rahman, M.M., Dutta, R.N., Mukherjee, S.C., Pati, S. and Kar, P.B. 2018. Groundwater arsenic contamination in the Ganga River basin: a future health danger. Int. J. Environ. Res. Public Health, 15: 180-190.

Chakraborty, S., Alam, M.O., Bhattacharya, T. and Singh, Y.N. 2014. Arsenic accumulation in food crops: a potential threat in Bengal Delta Plain. Water Quality, Exposure and Health, 6: 233-246.

Chauhan, V.S., Nickson, R., Chauhan, D., Iyengar, L. and Sankararamakrishnan, N. 2009. Ground water geochemistry of Ballia district, Uttar Pradesh, India and mechanism of arsenic release. Chemosphere, 75: 83-91.

Chikkanna, A., Mehan, L., Sarath, P. and Ghosh, D. 2019. Arsenic exposures, poisoning, and threat to human health: arsenic affecting human health. In: Environmental Exposures and Human Health Challenges, IGI Global, pp. 86-105.

Cullen, W.R. and Reimer, K.J. 1989. Arsenic speciation in the Environment. Chem. Rev., 89: 713-764.

Dey, S. 2017. Mission to make 28,000 habitations arsenic-free by 2021. https://timesofindia.indiatimes.com/india/mission-to-make-28000habitations-arsenic-free-by-2021/articleshow/57952655.cms

Dixit, R., Malaviya, D., Pandiyan, K., Singh, U.B., Sahu, A., Shukla, R., Singh, B.P., Rai, J.P., Sharma, P.K. and Lade, H. 2015. Bioremediation of heavy metals from soil and aquatic environment: an overview of principles and criteria of fundamental processes. Sustain., 7: 2189-2212.

Dontala, S.P., Reddy, T.B. and Vadde, R. 2015. Environmental aspects and impacts its mitigation measures of corporate coal mining. Procedia Earth and Planetary Sci., 11: 2-7.

Dunivin, T.K., Yeh, S.Y. and Shade, A. 2019. A global survey of arsenic related genes in soil microbiomes. BioRxiv, 44: 55-102.

Edwards, K.J., Bond, P.L., Gihring, T.M. and Banfield, J.F. 2000. An archaeal iron-oxidizing extreme acidophile important in acid mine drainage. Sci., 287: 1796-1799. 
Ellis, P.J, Conrads, T., Hille, R. and Kuhn, P. 2001. Crystal structure of the $100 \mathrm{kDa}$ arsenite oxidase from alcaligenes faecalis in two crystal forms at $1.64 \AA$ and $2.03 \AA$. Structure, 9: 125-132.

Fernández, M., Udaondo, Z., Niqui, J.L., Duque, E. and Ramos, J.L. 2014. Synergic role of the two ars operons in arsenic tolerance in Pseudomonas putida KT2440. Environ. Microbiol. Rep., 6: 483-489.

Firrincieli, A., Presentato, A., Favoino, G., Marabottini, R., Allevato, E., Stazi, S.R., ScaraSciencea-mugnozza, G., Harfouche, A., Petruccioli, M. and Zannoni, D. 2019. Identification of resistance genes and response to arsenic in Rhodococcus aetherivorans BCP1. Front. Microbiol., 10: 888-898.

Fournier, P.E., Vallenet, D., Barbe, V., Audic, S., Ogata, H., Poirel, L., Richet, H., Robert, C., Mangenot, S. and Abergel, C. 2006. Comparative genomics of multidrug resistance in Acinetobacter baumannii. PLoS Genetics, 2: e7.

Gorny, J., Billon, G., Noiriel, C., Dumoulin, D., Lesven, L. and Madé, B. 2018. Redox behaviour of arsenic in the surface sediments of the Marque River (Northern France). J. Geochem. Explor., 188: 111-122.

Gupta, A. and Singh, E.J. 2019. Arsenic-iron relationships in aquifers of North East India: implications for public health and the environment. environ. Manage., 63: 437-443.

Hajalilou, B., Mosaferi, M., Khaleghi, F., Jadidi, S., Vosugh, B. and Fatehifar, E. 2011. Effects of abandoned arsenic mine on water resources pollution in north west of Iran. Health Promotion Perspect., 1: $62-72$.

Hedges, R. and Baumberg, S. 1973. Resistance to arsenic compounds conferred by a plasmid transmissible between strains of E.coli. J. Bacteriol., 115: 459-469.

Herath, I., Vithanage, M., Bundschuh, J., Maity, J.P. and Bhattacharya, P. 2016. Natural arsenic in global groundwaters: distribution and geochemical triggers for mobilization. Curr. Pollut. Rep., 2: 68-89.

Jha, S.K., Mishra, V.K., Damodaran, T., Sharma, D.K. and Kumar, P. 2017. Arsenic in the groundwater-occurrence, toxicological activities, and remedies. J. Environ. Sci. Health, 35: 84-103.

Ji, G. and Silver, S. 1992. Reduction of arsenate to arsenite by the arsC protein of the arsenic resistance operon of Staphylococcus aureus plasmid pI258. Proceed. Nat. Acad. Sci., 89: 9474-9478.

Jiang, Y, Guo, H., Jia, Y., Cao, Y. and Hu, C. 2015. Principal component analysis and hierarchical cluster analyses of arsenic groundwater geochemistry in the Hetao basin, Inner Mongolia. Chemie Der ErdeGeochem., 75: 197-205.

Jomova, K., Jenisova, Z., Feszterova, M., Baros, S., Liska, J., Hudecova, D., Rhodes, C. and Valko, M. 2011. Arsenic: toxicity, oxidative stress and human disease. J. Appl. Toxicol., 31: 95-107.

Kadushkin, A., Siddiqui, Z. and Shipin, O. 2004. Groundwater quality assessment and management in selected countries of East and Southeast Asia. 41 st CCOP Annual Session 15-18 November 2004, Tsukuba, Japan, 147-157.

Kar, S., Maity, J.P., Jean, J.S., Liu, C.C., Nath, B., Yang, H.J. and Bundschuh, J. 2010. Arsenic-enriched aquifers: occurrences and mobilization of arsenic in groundwater of Ganges Delta Plain, Barasat, West Bengal, India. Appl. Geochem., 25: 1805-1814.

Kotze, A.A., Tuffin, I.M., Deane, S.M. and Rawlings, D.E. 2006. Cloning and characterization of the chromosomal arsenic resistance genes from Acidithiobacillus caldus and enhanced arsenic resistance on conjugal transfer of ars genes located on transposon TnAtcArs. Microbiol., 152: 3551-3560.

Kumari, N. and Jagadevan, S. 2016. Genetic identification of arsenate reductase and arsenite oxidase in redox transformations carried out by arsenic metabolising prokaryotes-A comprehensive review. Chemosphere, 163: 400-412.

Kwon, J.C., Nejad, Z.D. and Jung, M.C. 2017. Arsenic and heavy metals in paddy soil and polished rice contaminated by mining activities in Korea. Catena J., 148: 92-100.
Li, Y., Zhang, B., Cheng, M., Li, Y., Hao, L. and Guo, H. 2016. Spontaneous arsenic (III) oxidation with bioelectricity generation in single-chamber microbial fuel cells. J. Hazard. Mat., 306: 8-12.

López-Maury, L., Florencio, F.J. and Reyes, J.C. 2003. Arsenic sensing and resistance system in the Cyanobacterium synechocystis sp. strain PCC 6803. J. Bacterio., 185: 5363-5371.

Ma, Y., Lin, J., Zhang, C., Ren, Y. and Lin, J. 2011. Cd (II) and As (III) bioaccumulation by recombinant $E$. coli expressing oligomeric human metallothioneins. J. Hazard. Mat., 185: 1605-1608.

Masto, R.E., Ram, L.C., George, J., Selvi, V.A., Sinha, A.K., Verma, S.K. and Prabal, P. 2011. Status of some soil trace elements and their potential human health risks around a coal beneficiation plant. Int. J. Coal Prep. Utiliz., 31: 61-77.

Mazumder, D.N.G. 2015. Health Effects Chronic Arsenic Toxicity. Handbook of Arsenic Toxicology, 2015, edn. DNGM Research Foundation, New Alipore, Kolkata, India, pp. 137-177.

McArthur, J., Banerjee, D., Hudson-Edwards, K., Mishra, R., Purohit, R., Ravenscroft, P., Cronin, A., Howarth, R., Chatterjee, A. and Talukder, T. 2004. Natural organic matter in sedimentary basins and its relation to arsenic in anoxic ground water: the example of West Bengal and its worldwide implications. Appl. Geochem., 19: 1255-1293.

McArthur, J.M. 2019. Arsenic in groundwater. Groundwater Development and Management: Issues and Challenges in South Asia. pp. 279-308. doi:10.1007/978-3-319-75115-3_12

Meliker, J.R., Avruskin, G.A., Slotnick, M.J., Goovaerts, P., Schottenfeld, D., Jacquez, G.M. and Nriagu, J.O. 2008. Validity of spatial models of arsenic concentrations in private well water. Environ. Res., 106: 42-50.

Milton, A.H., Hasan, Z., Rahman, A. and Rahman, M. 2001. Chronic arsenic poisoning and respiratory effects in Bangladesh. J. Occupat. Health, 43: 136-140.

Mirza, B.S., Sorensen, D.L., Dupont, R.R. and Mclean, J.E. 2017. New arsenate reductase gene (arrA) PCR primers for diversity assessment and quantification in environmental samples. Appl. Environ. Microbiol., 83: e02725-16.

Neyt, C., Iriarte, M., Thi, V.H. and Cornelis, G.R. 1997. Virulence and arsenic resistance in Yersiniae. J. Bacteriol., 179: 612-619.

Nookongbut, P., Kantachote, D., Krishnan, K. and Megharaj, M. 2017. Arsenic resistance genes of As-resistant purple nonsulfur bacteria isolated from As-contaminated sites for bioremediation application. J. Basic Microbiol., 57: 316-324.

Nordstrom, D.K. 2002. Worldwide occurrences of arsenic in ground water. Sci., 296: 2143-2145.

Omar, Y.Y., Parker, A., Smith, J.A. and Pollard, S.J. 2017. Risk management for drinking water safety in low and middle income countries-cultural influences on water safety plan (WSP) implementation in urban water utilities. Sci. Tot. Environ., 576: 895-906.

Ordóñez, E., Letek, M., Valbuena, N., Gil, J.A. and Mateos, L.M. 2005. Analysis of genes involved in arsenic resistance in Corynebacterium glutamicum ATCC 13032. Appl. Environ. Microbiol., 71: 6206-6215.

Oremland, R.S. and Stolz, J.F. 2003. The ecology of arsenic. Sci., 300: 939-944.

Oremland, R.S., Hoeft, S.E., Santini, J.M., Bano, N., Hollibaugh, R.A. and Hollibaugh, J.T. 2002. Anaerobic oxidation of arsenite in Mono Lake water and by a facultative, arsenite-oxidizing chemoautotroph, strain MLHE-1. Appl. Environ. Microbiol., 68: 4795-4802.

Palit, S., Misra, K. and Mishra, J. 2019. Arsenic Contamination in South Asian Regions: The Difficulties, Challenges and Vision for the Future. Separation Science and Technology, 11edn. Elsevier, pp. 113-123.

Pandey, P.K., Choubey, S., Verma, Y., Pandey, M. and Chandrashekhar, K. 2009. Biosorptive removal of arsenic from drinking water. Biores. Technol., 100: 634-637.

Patel, K.S., Sahu, B.L., Dahariya, N.S., Bhatia, A., Patel, R.K., Matini, 
L., Sracek, O. and Bhattacharya, P. 2017. Groundwater arsenic and fluoride in Rajnandgaon District, Chhattisgarh, northeastern India. Appl. Water Sci., 7: 1817-1826.

Philp, R.B. 2015. Ecosystems and Human Health: Toxicology and Environmental Hazards, Crc Press, London. doi: 10.1093/ acrefore/9780199389414.013.86

Prithivirajsingh, S., Mishra, S.K. and Mahadevan, A. 2001. Detection and analysis of chromosomal arsenic resistance in Pseudomonas fluorescens strain MSP3. Biochem. Biophys. Res. Commun., 280: 1393-1401.

Quinodóz, F.B., Maldonado, L., Blarasin, M., Matteoda, E., Lutri, V., Cabrera, A., Albo, J.G. and Giacobone, D. 2019. The development of a conceptual model for arsenic mobilization in a fluvio-eolian aquifer using geochemical and statistical methods. Environ. Earth Sci., 78: 206-216.

Ramanathan, A., Bhattacharya, P. and Tripathi, P. 2006. Arsenic in groundwater of the aquifers of central Gangetic plain of Uttar Pradesh, India. In Philadelphia annual meeting, pp. 22-25. https://doi: 10.1201/ b11334-26

Rosen, B.P. 2002. Biochemistry of arsenic detoxification. FEBS lett., 529: 86-92.

Rosenstein, R., Peschel, A., Wieland, B. and Götz, F. 1992. Expression and regulation of the antimonite, arsenite, and arsenate resistance operon of Staphylococcus xylosus plasmid pSX267. J. Bacteriol., 174: 3676-3683.

Ryan, R., Ryan, D. and Dowling, D. 2005. Multiple metal resistant transferable phenotypes in bacteria as indicators of soil contamination with heavy metals. J. Soils and Sediments, 5: 95-100.

Saha, D. and Ray, R.K. 2019. Groundwater resources of India: potential, challenges and management. Groundwater Development and Management, Springer, South Asia. doi:10.1007/978-3-319-75115-3

Saltikov, C.W., Cifuentes, A., Venkateswaran, K. and Newman, D.K. 2003. The ars detoxification system is advantageous but not required for As (V) respiration by the genetically tractable Shewanella species strain ANA-3. Appl. Environ. Microbiol., 69: 2800-2809.

Sandhi, A., Greger, M., Landberg, T., Jacks, G. and Bhattacharya, P. 2017. Arsenic concentrations in local aromatic and high-yielding hybrid rice cultivars and the potential health risk: a study in an arsenic hotspot. Environ. Moniter. Assess., 189: 184-196.

Santini, J.M. and Hoven, R.N.V. 2004. Molybdenum-containing arsenite oxidase of the chemolithoautotrophic arsenite oxidizer NT-26. J. Bacteriol., 186: 1614-1619.

Santra, S.C., Samal, A.C., Bhattacharya, P., Banerjee, S., Biswas, A. and Majumdar, J. 2013. Arsenic in foodchain and community health risk: a study in Gangetic West Bengal. Proced. Environ. Sci., 18: 2-13.

Sato, T. and Kobayashi, Y. 1998. The ars Operon in the skin element of Bacillus subtilis confers resistance to Arsenate and Arsenite. J. Bacteriol., 180: 1655-1661.

Satyapal, G., Rani, S. and Kumar, M. 2016. Potential role of arsenic resistant bacteria in bioremediation: current status and future prospects. J. Microbiol. Biochem. Technol., 8: 256-258.

Shah, B. 2010. Arsenic-contaminated groundwater in Holocene sediments from parts of Middle Ganga Plain, Uttar Pradesh, India. Curr. Sci., 98: 10-21.

Shan, Y., Mehta, P., Perera, D. and Varela, Y. 2019. Cost and efficiency of arsenic removal from groundwater: a review. UNU-INWEH Report Series, Issue 05. United Nations University Institute for Water, Environment and Health, Hamilton, Canada. https://inweh.unu.edu/ cost-and-efficiency-of-arsenic-removal-from-groundwater-a-review/

Shankar, S. and Shanker, U. 2014. Arsenic contamination of groundwater: a review of sources, prevalence, health risks, and strategies for mitigation. Scientific World J., https://doi: 10.1155/2014/304524
Sichone, K. 2019. Control of leachate contamination from mine wastes through an appropriate operating practice. In: Gaustad G. et al. (eds) Rewas 2019. The Minerals, Metals \& Materials Series, Springer, Cham.

Silver, S. and Phung, L.T. 2005. Genes and enzymes involved in bacterial oxidation and reduction of inorganic arsenic. Appl. Environ. Microbiol., 71: 599-608.

Singh, G.B., Gupta, S., Srivastava, S. and Gupta, N. 2011. Biodegradation of carbazole by newly isolated Acinetobacter spp. Bullet. Environ. Contam. Toxicol., 87: 522-526.

Singh, P.K. and Singh, R.S. 2016. Environmental and social impacts of mining and their mitigation. In: Kolkata (India): National Seminar ESIMM-2016.

Singh, R. 2014. Microorganism as a tool of bioremediation technology for cleaning Environment: A review. Proceed. Int. Acad. Ecol. Environ. Sci., 4: 1-6.

Smedley, P. and Kinniburgh, D. 2002. A review of the source, behaviour and distribution of arsenic in natural waters. Appl. Geochem., 17: 517-568.

Sprague, D.D. and Vermaire, J.C. 2018. Legacy arsenic pollution of lakes near cobalt, Ontario, Canada: arsenic in Lake water and sediment remains elevated nearly a century after mining activity has ceased. Water, Air, \& Soil Pollut., 229: 87-105.

Sylvia, D.M., Fuhrmann, J.J., Hartel, P.G. and Zuberer, D.A. 2005. Principles and Applications of Soil microbiology. Pearson Prentice Hall Upper Saddle River, New Jersy.

Tian, H., Wang, J., Li, J., Wang, Y., Mallavarapu, M. and He, W. 2019. Six New Families of Aerobic Arsenate Reducing Bacteria: Leclercia, Raoultella, Kosakonia, Lelliottia, Yokenella, and Kluyvera. Geomicrobiol J., 36: 339-347.

Tomar, N.S. 2017. Fluoride and Arsenic in Drinking Water. 09 March 2017. http://www.who.int/water_sanitation_health/en/poster8.pdf

Turner, R.J. 2001. Tellurite toxicity and resistance in Gram-negative bacteria. Rec. Res. Develop. Microbiol., 5: 69-77.

Verma, S. and Kuila, A. 2019. Bioremediation of heavy metals by microbial process. Environ. Technol. Innovat., 14: 100369-100381.

Wang, G., Kennedy, S.P., Fasiludeen, S., Rensing, C. and Dassarma, S. 2004. Arsenic resistance in Halobacterium sp. strain NRC-1 examined by using an improved gene knockout system. J. Bacteriol., 186: 3187-3194.

Wang, L., Chen, S., Xiao, X., Huang, X., You, D., Zhou, X. and Deng, Z. 2006. arsRBOCT arsenic resistance system encoded by linear plasmid pHZ227 in Streptomyces sp. strain FR-008. Appl. Environ. Microbiol., 72: 3738-3742.

Wei, S., Zhang, H. and Tao., S. 2019. A review of arsenic exposure and lung cancer. Toxicol. Res., 8: 319-327.

WHO 2010. Exposure to arsenic: a major public health concern. Geneva: Public Health Environ., 1: 1-5.

Willsky, G.R. and Malamy, M.H. 1980. Effect of arsenate on inorganic phosphate transport in E.coli. J. Bacteriol., 144: 366-374.

Zhang, D., Wang, S., Wang, Y., Gomez, M.A. and Jia, Y. 2019. The long-term stability of calcium arsenates: Implications for phase transformation and arsenic mobilization. J. Environ. Sci., 84: 29-41.

Zhang, J., Cao, T., Tang, Z., Shen, Q., Rosen, B.P. and Zhao, F.J. 2015. Arsenic methylation and volatilization by arsenite Sadenosylmethionine methyltransferase in Pseudomonas alcaligenes NBRC14159. Appl. Environ. Microbiol., 81: 2852-2860.

Zhao, C., Zhang, Y., Chan, Z., Chen, S. and Yang, S. 2015. Insights into arsenic multi-operons expression and resistance mechanisms in Rhodopseudomonas palustris CGA009. Front. Microbiol., 6: 986-997. 